\title{
アデノシン三リン酸測定器および試薬間における相関関係と 医療分野に打ける適切な活用
}

\author{
大石 貴幸1) $\cdot$ 四宮 聡 ${ }^{2)} \cdot$ 伏見 $\quad 3^{3)} \cdot$ 大久保 憲 3

\section{Correlation Between Instrument Reagent Adenosine Triphosphate and Tolerance Settings and Appropriate Use in The Medical Field}

\author{
Takayuki OHISHI ${ }^{1)}$, Satoshi ShINOMiYa ${ }^{2)}$, Ryo Fushimi ${ }^{3)}$ and Takashi OKUBO ${ }^{3)}$ \\ 1) Department of Infection Control and Prevention, Osaki Citizen Hospital, \\ ${ }^{2)}$ Department of Infection Control and Prevention, Mino City Hospital, \\ 3) Tokyo Healthcare University Postgraduate School \\ $(2013$ 年 4 月 10 日 受付 $\cdot 2013$ 年 7 月 26 日 受理)
}

\begin{abstract}
要旨
国内で汎用されているアデノシン三リン酸 (Adenosine Tri-Phosphate; ATP) 測定器と試薬を用 いて，ATP 標準液と標準菌株懸濁液を測定し相関関係を明確にすることで，ATPを指標とした医 療分野に颃ける医療機器の清浄度評価と再洗浄の目安となる許容值設定について検討した。 Lumitester PD-20 とATP 測定試薬 LuciPac Pen (A 法), CleanTrace UNG3 とATP 測定試薬 CleanTrace UXL(B 法) および UNG3 とATP 測定試薬 CleanTrace AQT (C 法)を用いて, 蒸留水, ATP 粉末試薬を蒸留水に溶解した標準液, 主要 4 菌種の標準菌株懸濁液を測定した。結果, 蒸留 水は ATP 陽性となり，一般細菌，真菌の測定限界値は各々 $10^{2} \sim 10^{3}, 2.0 \mathrm{CFU} /$ assay だった. ATP 標準液および標準菌株懸濁液の測定值は A 法, B 法, C 法の順に高值となり, いずれの方法 でも測定值は相関係数 0.98 以上と高い相関を示したが絶対值ではなく, 各測定法間での測定值の 比較には問題があると考えられた。 また, どの方法でも高感度, 低特異度なため, 医療現場で ATP を清浄度評価とする際は, 医療機器洗浄後など菌残留が許容される場合に有用であることが 示唆された. 許容值に関しては, 洗浄後の残留 ATP の平均值を調べ, 洗浄方法別の值を設定する 必要がある.
\end{abstract}

Key words : アデノシン三リン酸, 試薬間比較, 相関係数, 許容值

\section{はじめに}

医療現場での再処理業務を行う上で, 医療機器が確実 に清浄化されたかを判定することは，医療の質を担保す るための重要な要素のひとつである．清浄度の判定法と しては細菌培養が恒常的に実施されてきたが, 培養検査 は判定まで約 24 時間必要であり, 現場での迅速な判定 は困難で, かつ, 培養方法によっては検出不可能な細菌 類があることも問題となってきた1).

1) 大崎市民病院感染管理部， 2 ) 箕面市立病院チーム医療推進部,

3) 東京医療保健大学/大学院感染制御学
このような欠点を補える方法として, 近年, アデノシ ン三リン酸 (Adenosine Tri-Phosphate; ATP)を指標と した清浄度評価が注目されている2).ATP 測定法は簡 便, 迅速, 高感度との理由から, 主に食品衛生の分野で 利用され，細菌培養検査との相関性が高く，医療現場で の清浄度評価にも有効との報告がある2 7).

国内で市販されているATP 測定器は, ATPの分解 産物であるアデノシン一リン酸 (adenosine MonoPhosphate; AMP) も測定可能な Lumitester ${ }^{\circledR}$ PD-20 (Kikkoman 社), ATPのみの測定となる CleanTrace ${ }^{\mathrm{TM}}$ UNG3 (3M 社), SystemSure Plus, Ensure(ともに 
Hygiena 社), AccuPoint (Neogen 社)などあるが，国 内の医療分野に㧍いては, Lumitester ${ }^{\circledR}$ PD-20 (PD-20) と CleanTrace ${ }^{\mathrm{TM}} \mathrm{UNG}$ (UNG3)の使用頻度が高い。し かし, PD-20 とUNG3 では, 同一検体を測定しても結 果に差異があり，メーカー発表ながら感度や特異度にも 相違があるとされており, 学術発表等においてATP 測 定により医療機器の清浄度を評価した場合, 使用した ATP 測定器を明記しなければ，誤った解釈に繋がる可 能性がある.

そこで, 本研究では PD-20 と PD-20 専用 ATP 測定 試薬である LuciPac ${ }^{\circledR}$ Pen (LPP), UNG3 と UNG3 専用 ATP 測定試薬である CleanTrace ${ }^{\mathrm{TM}}$ UXL ( UXL), CleanTrace ${ }^{\mathrm{TM}} \mathrm{AQT}(\mathrm{AQT})$ を用いて, ATP 粉末試薬を 注射用蒸留水 (大塚蒸留水: 以下, 蒸留水)に溶解した標 準液と主要な標準菌株懸濁液を測定し, 各機種·試薬間 の相関関係を明確にした上で，ATPを指標とした医療 現場に打ける医療機器の清浄度評価と再洗浄の目安とな る許容值設定について検討する.

\section{材料と方法}

PD-20 と LPP (A 法), UNG3 と UXL (B 法)および UNG3 と AQT (C 法)を用いて, 蒸留水とATP 標準液, Staphylococcus aureus ( $S$. aureus), Escherichia coli (E. coli), Pseudomonas aeruginosa (P. aeruginosa), Candia albicans（C. albicans）の標準菌株懸濁液を測定した．実 験環境は室温約 $23^{\circ} \mathrm{C}$ の屋内, ATP 測定試薬は使用前に 1 時間以上室温放置し, 検体採取棒に検体を $10 \mu \mathrm{L}$ 滴下 後, 30 秒以内に 10 回ずつ計測した. 測定単位は測定 試薬ごとにどれほどの量が採取されたかの換算值表現 で, ATP 標準液は mol/ assay, 標準菌株懸濁液は McFarland/assay とした. 測定に使用したATP 測定試 薬のロット番号は LLP が 20121107P, UXL は 20JU1 2013, AQT で 09JU1 2013 であった.

\section{1. コントロール測定}

ATP 測定器は, ATP が全く存在しない場合でも, 発 光試薬自体がある程度発光を生じるため 0 とはならな (8).このためコントロールが必要であり, 本研究では ATP 粉末試薬や標準菌株を溶解する蒸留水をコント ロールとし， $10 \mu \mathrm{L}$ を各 ATP 測定試薬にてそれぞれ 10 回測定し平均值を算出した.

\section{ATP 標準液測定}

ATP 粉末試薬 (Adenosine-5'-triphosphate : オリエ ンタル酵母工業侏) を蒸留水に溶解し, $10^{-12} \mathrm{~mol} / \mathrm{L}$, $10^{-11} \mathrm{~mol} / \mathrm{L}, \quad 10^{-10} \mathrm{~mol} / \mathrm{L}, \quad 10^{-9} \mathrm{~mol} / \mathrm{L}, 10^{-8} \mathrm{~mol} / \mathrm{L}$, $10^{-7} \mathrm{~mol} / \mathrm{L}, 10^{-6} \mathrm{~mol} / \mathrm{L}, 10^{-5} \mathrm{~mol} / \mathrm{L}$ の希釈系列を作製 後, 各々を各試薬で 10 回ずつ測定し, 平均值を算出し た。

\section{3. 標準菌株懸濁液測定}

測定には, S. aureus の ATCC 29213 株，E. coli の ATCC 25922 株, P. aeruginosa の ATCC 27853 株, C. albicans の ATCC 10231 株の 4 標準菌株を用いた。標 準菌株を初代加ら継代 (24 時間 $35^{\circ} \mathrm{C}$ 培養)して得られた 第 3 世代株を蒸留水に懸濁し， $\mathrm{BD}$ フェニックス ック $(\mathrm{BD}$ 社)を用いて $0.50 \mathrm{McF}$ arland に調製， $0.5 \times$ $10^{-1}$ McFarland, $\quad 0.5 \times 10^{-2}$ McFarland, $0.5 \times 10^{-3}$ McFarland, $\quad 0.5 \times 10^{-4}$ McFarland, $\quad 0.5 \times 10^{-5}$ McFarland の希釈系列を作製後, 各試薬にて 10 回測定 し, 平均值を算出した. 標準菌株懸濁液の生菌数確認の ため, S. aureus, E. coli, P. aeruginosa はトリプチケース ソイ寒天培地, C. albicans はレシチン・ポリソルベー ト 80 添加トリプチケースソイ寒天培地に各希釈系列の 懸濁液を $10 \mu \mathrm{L}$ 添加塗布した。この方法を各々 3 回実 施し, 平均值を算出した.

\section{結果}

ATP 測定值は発光度 (Luminescence) で表し，単位は RLU (相対的発光量), 実測值は全て対数変換 $\left(\log _{10}\right)$ L た. Table 1 には蒸留水とATP 標準液を測定した際の 平均值 (average: AV) と標準偏差 (standard deviation: SD), Fig. 1 には平均值をもとにしたATP 測定曲線を 示す。また, 各 ATP 測定試薬でATP 標準液を測定し た際の相関係数と近似直線式はそれぞれ， A 法-B 法 : 0.99786, $\mathrm{y}=1.0564 \mathrm{x}+0.3709$ (Fig. 2), A 法 $-\mathrm{C}$ 法 : $0.98781, y=1.0823 \mathrm{x}+0.6644$ (Fig. 3), B 法 $-\mathrm{C}$ 法 : $0.99760, \mathrm{y}=1.0303 \mathrm{x}+0.2677$ (Fig. 4) となり，いずれ も正の相関を示した.

各標準菌株懸濁液の ATP 測定曲線と相関係数, 平均 值をもとにした近似直線式を Fig. 5 に表す。いずれも 正の相関を呈した.

Table 1 Measurement of standardized ATP $(n=10)$

\begin{tabular}{c|ccc|ccc}
\hline \multirow{2}{*}{$\begin{array}{c}\text { ATP } \\
\text { (mol/assay) }\end{array}$} & \multicolumn{3}{|c|}{ AV(log) } & \multicolumn{3}{c}{ SD } \\
\cline { 2 - 7 } & A test & B test & C test & A test & B test & C test \\
\hline $10^{-17}$ & 0.84 & 1.15 & 1.33 & 0.16 & 0.10 & 0.07 \\
$10^{-16}$ & 0.94 & 1.16 & 1.38 & 0.07 & 0.09 & 0.06 \\
$10^{-15}$ & 1.02 & 1.39 & 1.68 & 0.10 & 0.07 & 0.06 \\
$10^{-14}$ & 1.35 & 1.99 & 2.37 & 0.08 & 0.04 & 0.15 \\
$10^{-13}$ & 2.21 & 2.87 & 3.42 & 0.04 & 0.06 & 0.06 \\
$10^{-12}$ & 3.21 & 3.90 & 4.44 & 0.11 & 0.05 & 0.08 \\
$10^{-11}$ & 4.22 & 4.90 & 5.31 & 0.06 & 0.05 & 0.09 \\
$10^{-10}$ & 5.23 & 5.70 & 5.97 & 0.11 & 0.03 & 0.05 \\
\hline Distilled & 0.70 & 1.14 & 1.29 & 0.06 & 0.05 & 0.09 \\
water & & & & & & \\
\hline
\end{tabular}

A test: Lumitester PD-20 and Luci Pac Pen B test: Clean Trace UNG 3 and Clean Trace UXL C test: Clean Trace UNG 3 and Clean Trace AQT 


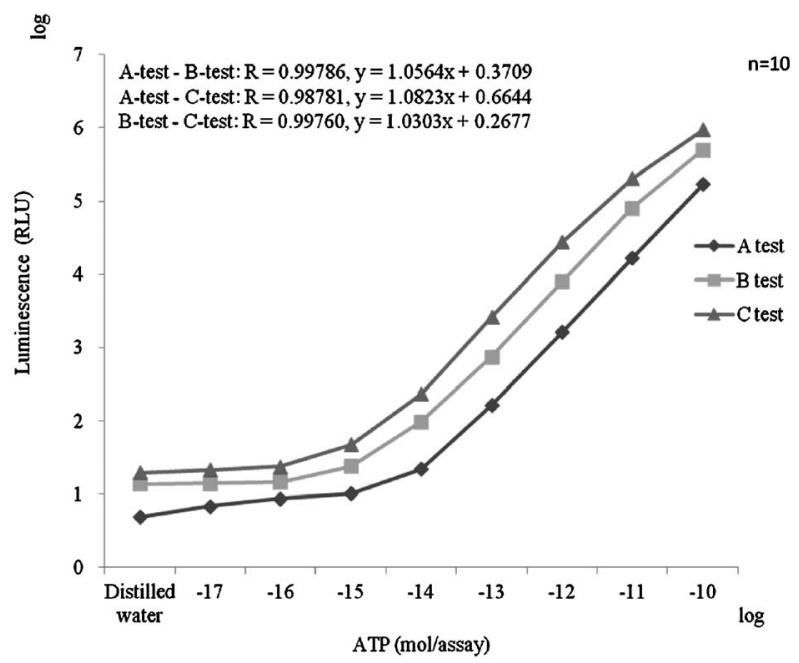

Fig. 1 Measurement of standardized ATP in each reagent

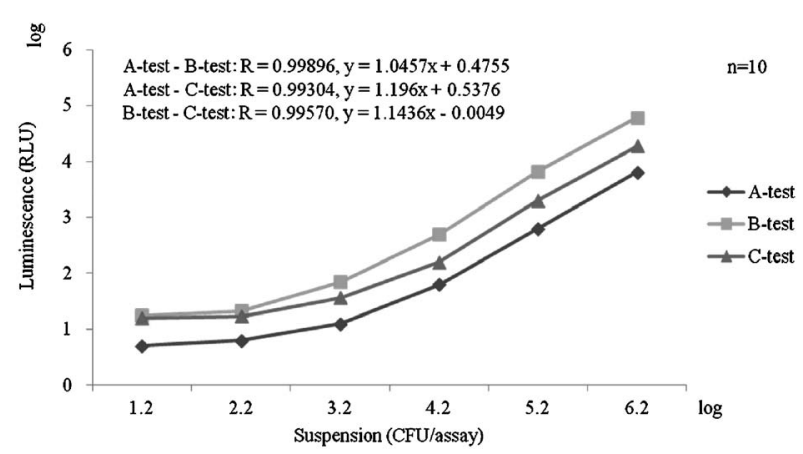

Fig. 2 Measurement of $S$. aureus suspension in each reagent

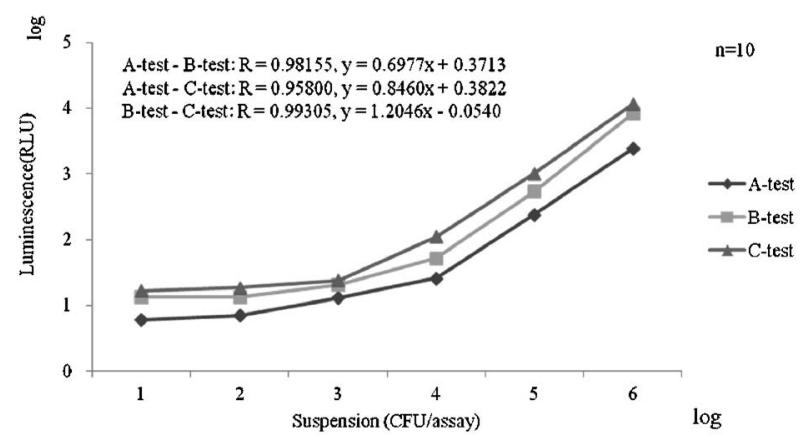

Fig. 3 Measurement of E. coli suspension in each reagent

\section{考察}

各 ATP 測定試薬におけるATP 標準液と測定值の相

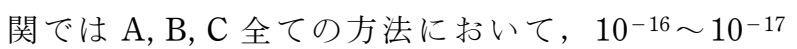
$\mathrm{mol} /$ assay のレンジで, 測定曲線がプラトー化し測定限 界値と考えられた. 各測定值の間には, 全て非常に強い 相関 $(\mathrm{R}=0.98$ 以上) $)$ 認めたが, $\mathrm{A}$ 法, B 法, C 法の順 に高值となることが判明した. なた， 3 方法間の近似直

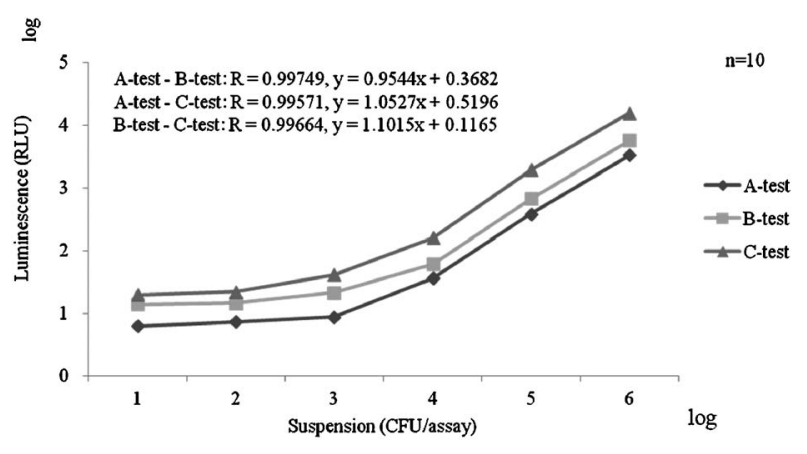

Fig. 4 Measurement of $P$. aeruginosa suspension in each reagent

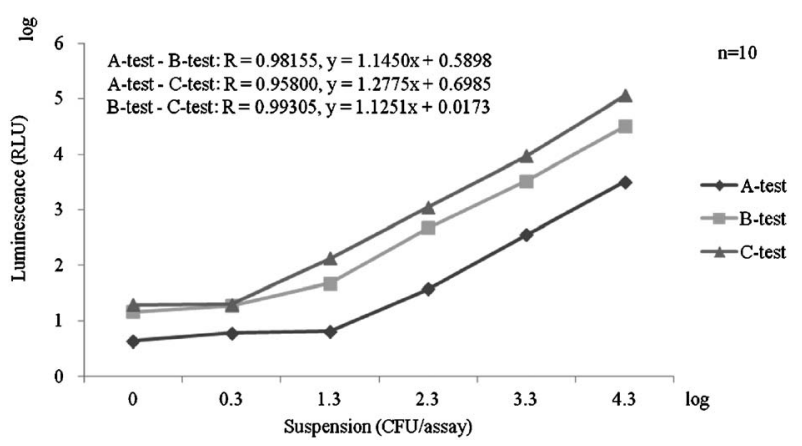

Fig. 5 Measurement of $C$. albicans suspension in each reagent

線の傾きはほぼ 1 となり，切片が $\mathrm{A}$ 法-B 法間で $0.3 \mathrm{log}$, A 法-C 法間で $0.6 \log , \mathrm{B}$ 法-C 法間で $0.3 \log$ となった ことから，各方法間での測定值を補正するには，A 法 の測定值に $0.3 \log$ を加算した值が B 法の測定值に， A 法の測定值に $0.6 \log$ を加算した值が C 法の測定值に， B 法の測定值に $0.3 \log$ を加算した值が C 法の測定值に 相当することが示唆された.

ATP 測定試薬には, 細菌の細胞壁や細胞膜を溶解し ATP を抽出するための試薬と, 抽出されたATPを発 光させるための発光試薬が添加されている ${ }^{8)}$. 今回の実 験では, ATP 単体の試薬を検体としているため, 抽出 試薬が測定結果に影響を及ぼすことは考えにくく，発光 試薬の添加量の差か, 発光を数值化する際の係数が ATP 測定試薬間で異なる可能性がある。 B 法と C 法 は, 同じ測定器を用いて測定するため, 同じ検体の結果 に差異を認めることは，発光量自体に差があることを意 味することから，各 ATP 測定試薬間での測定值の相違 は, 発光試薬量が関係している可能性が強く示唆された.

各標準菌株懸濁液の測定值と菌数との相関では，全て において A 法が最も低值となり, 次いで B 法, C 法の 順となり，ATP 標準液の測定結果と整合性があった。 S. aureus, E. coli, P. aeruginosa では全ての方法において $10^{2} \sim 10^{3} \mathrm{CFU} /$ assay, C. albicans では $2.0 \mathrm{CFU} /$ assay 
で蒸留水と近似值になり測定限界值と考えられた。一般 細菌に比べて，C. albicans でATP 測定值が高值となっ たのは，微生物によって細胞当りのATP 含量が異なる (一般細菌で $10^{-18} \mathrm{~mol} / \mathrm{cell}$, 酵母 ·真菌で $10^{-15} \mathrm{~mol} /$ cell)ことが要因と考えられた ${ }^{9)}$.

標準菌株懸濁液を測定した際の各 ATP 測定試薬にお ける相関では，全ての試薬において $\mathrm{R}=0.95$ 以上の高 い相関を示し, 測定值は A 法を基準とした場合, B 法 では $1.2 \sim 1.3$ 倍, $\mathrm{C}$ 法では $1.4 \sim 1.5$ 倍となった. 3 方 法間の近似直線の傾きは, ぞの菌種に拈いてもほぼ 1 となったことから，各方法間での補正を実施する場合， 乗算する必要はないが, 各菌種, 方法間で切片の相違が 著しいため定数を加算することができない，つまり菌 種・方法別の切片に応じた数值を加算することになる.

以上により, ATP 標準液や標準菌株懸濁液測定にお ける A 法, B 法, C 法の相関は非常に強く, 近似直線 の傾きはほぼ 1 となり, 測定值は同一の検体量を測定 すると, A 法, B 法, C 法の順で $0.3 \log$ 間隔で高くな ることが判明した.しかしながら, 実測の際には, 本研 究のような一定量を滴下しての測定ではなく, 先端が綿 棒タイプの試薬(UXL, LPP)は拭き取って, 溝状タイプ (AQT) では液体に浸けるため測定量に差が生じる。こ のためひとつの測定対象物に対して複数の ATP 試薬を 混在させて測定することは, 測定結果の標準性に欠け, 䛊評価に繋がるため注意が必要である.

また，実際の医療現場でATP を測定する場合，ATP 標準液のような ATP のみで構成された検体を計測する ことは考えにくく，様々な細菌や有機物の混合液，ある いは付着物とともに測定すると推測される．特に綿棒夕 イプの試薬は，拭き取り時の圧力によって，吸収あるい は付着する有機物等の検体量に差異ができ, 誤差を生じ る原因となるため, 慎重な結果の解釈が必須となろう.

このような現状と本研究結果から医療現場での ATP 測定の利用法について言及する。既に国内外から ATP 測定による環境や軟性内視鏡の清浄度評価, 手洗い効果 の判定に有用との報告がある2,10,11)。環境や軟性内視鏡 の清浄度評価では測定值が低い場合，清浄と判断できう るとしている報告が多く, 一方, 手洗い効果の判定で は, 手洗い後の測定值と細菌数の相関が悪いため, 清浄 効果の判定には不向きとする意見が多数を占める. 本研 究で示した通り, ATP 測定ではコントロールとした蒸 留水でも測定值が 0 とはならず，ATP 標準液や標準菌 株懸濁液の低濃度では, 測定限界があるため, 低測定值 を無菌とするには特異度が低く問題がある。また， ATP は細胞内のミトコンドリアや TCA サイクルによ って産生される物質であり，これらを持たないウイルス では，ATPを指標とした清浄度評価は意味をなさない。

つまり，医療現場でATP を測定した結果，測定值が
低くなったとしても, 対象物に微生物が存在しない証左 とはなり得ない。この観点から, 微生物が検出されては いけない滅菌物や, 特定の微生物を殺滅する消毒効果の 指標としてATP 測定を用いるのは問題といえる。しか し，測定值はある程度の菌量があれば必ず上昇すること から，測定対象物がコントロール值より高值となった場 合は，ATPがほぼ確実に存在していることになり，対 象物の污染度の評価としては感度が高く有用となる。ゆ えに，医療現場でATP を清浄度評価に用いる際は医療 機器の洗浄後など菌残留が許容される場合の評価に有用 であり, 無菌性を求める消毒や滅菌の場合には不適切で あると考えられる。

実際の評価方法としては洗浄後にATP を複数回測定 し，ネガティブコントロールとなる数值を決定した後， 使用後の対象物の洗浄が終了した時点でATPを測定 し，ネガティブコントロール值より 2SD を超えた結果 が得られた場合は再度洗浄をやり直す，といった方法が 有効であろう。従って，ATP 測定は目的とする対象物 がぞのような工程を経てきたものかを確認し，背景を考 慮した判定方法を確立する必要があると考えられた。ま た，その際には同じ測定器および試薬を継続して使用す ることが，誤判定を回避できる方法となる.

利益相反について：ATP の測定にあたっては, キッコーマン バイオケミファ株式会社から試薬と測定器, スリーエムヘルス ケア株式会社からは試薬の提供を受けた。

\section{文献}

1）渡部博一, 関川浩司 : ATP · AMP ふき取り検查を用 いた消化器内視鏡の再処理工程管理に関する検討. 感 染制御 2010; 6(3): 237-44.

2) Fushimi R, Takashina M, Yoshikawa H, Kobayashi H, Okubi $\mathrm{T}$, Nakata $\mathrm{S}$, et al: : Comparison of adenosine triphosphate, microbiological load, and residual protein as indicators for assessing the cleanliness of flexible gastrointestinal endoscopes. Am J Infect Control 2012; 41: 161-4.

3）白根智子, 稲垣典子, 今井さゆり, 勝野綾子, 山本久 代，山森美也子，他：ATP 子き取り検査を用いた給食 管理実習に打活染度調査. 医と生物学 2011; 155 (10): 648-56.

4）石橋佳世子, 尾山容子, 縫田和宏, 梅下浩司, 伏見 了, 宮下義弘, 他 : アデノシン三リン酸 (ATP)を指標 とした上部消化管用内視鏡表面污染の把握と洗浄効果 の判定. 日手術医会誌 2011; 32: 165-7.

5）久田友治，太田光紀，垣花シゲ：アデノシン三リン酸 測定を用いた手術時手洗い評価の臨床的意義. 環境感 染誌 2011; 26: 83-6.

6）吉本和仁，花村祥太郎，山村詠一，先山あゆみ，阿曽 沼邦央, 猪 聡志, 他 : 内視鏡の器械と技術 アルカ リイオン水の送水による内視鏡レンズ洗浄の有用性. Prog Dig Endosc 2011; 78: 34-6.

7）岡山晴香, 久田友治, 具志堅興治, 宮城孝徳, 謝名堂 昌人：アデノシン三リン酸 (ATP) 測定を用いたグロー 
ブジュース法の開発. 日手術医会誌 2011; 32: 60-1.

8）羽毛田靖：ATP 法による細菌数測定装置の基礎と応 用. 防菌防徽 1997; 25: 457-66.

9）間㴊 創, 木川りか, 佐野千絵 : 文化財公開施設等に おける ATP 拭き取り検查の活用について. 保存科学 2009; 49: 1-11.

10) Alfa MJ, Fatima I, Olson N: The adenosine triphosphate test is a rapid and reliable audit tool to assess manual cleaning adequacy of flexible endoscope channels. Am J Infect Control 2013; 41: 249-53.

11) Alfa MJ, Fatima I, Olson N: Validation of adenosine triphosphate to audit manual cleaning of flexible endoscope channels. Am J Infect Control 2013; 41: 245-8.

〔連絡先 : $=989-6183$ 宮城県大崎市古川千手寺 2-3-10 大崎市民病院感染管理部 大石貴幸 E-mail: ict-och@h-osaki.jp]

\title{
Correlation Between Instrument Reagent Adenosine Triphosphate and Tolerance Settings and Appropriate Use in The Medical Field
}

\author{
Takayuki OHISHI ${ }^{1)}$, Satoshi SHINomiYA ${ }^{2)}$, Ryo Fushimi ${ }^{3)}$ and Takashi OKUBO ${ }^{3)}$ \\ ${ }^{1)}$ Department of Infection Control and Prevention, Osaki Citizen Hospital, \\ ${ }^{2)}$ Department of Infection Control and Prevention, Mino City Hospital, \\ ${ }^{3)}$ Tokyo Healthcare University Postgraduate School
}

\begin{abstract}
Recently, adenosine triphosphate (ATP) has been developed as an index for cleanliness evaluation. In Japan, Kikkoman's Lumitester ${ }^{\circledR}$ PD-20 (PD-20) with the reagent LuciPac ${ }^{\circledR}$ Pen (LPP) and 3M's CleanTrace ${ }^{\mathrm{TM}}$ UNG3 (UNG3) with the reagents Clean Trace ${ }^{\mathrm{TM}} \mathrm{UXL}$ (UXL) or Clean Trace $^{\mathrm{TM}} \mathrm{AQT}$ (AQT) are frequently used. However, correlation of the test results between these devices and reagents as well as permissible values are not clear. This study clarified the correlation and measurement limits with standardized ATP solutions and major bacterial suspensions measured using the following ATP devices and reagents: PD-20 with LPP (A-test), UNG3 with UXL (B-test), and UNG3 with AQT (C-test). Furthermore, cleanliness evaluation in medical field as an index of ATP and tolerance settings for repeat processing (cleaning, disinfection or sterilization) were assessed. Distilled water (control), standardized ATP solution, and four types of strain suspensions were measured 10 times with $10 \mu \mathrm{L}$ of each reagent. All measured values were logarithmically converted. Distilled water had the following values: A-test 0.70 RLU, B-test 1.14 RLU, C-test 1.29 RLU. In all reagents, standardized ATP solution was within the range measurement limit of $10^{-16} \sim 10^{-17} \mathrm{~mol} /$ assay. The quantitative relationship for each reagent was positively correlated within the measurement range of the standardized ATP solution. The measured values of the standardized ATP and standardized strain suspensions increased in the order A-test, B-test and C-test. The measured values showed a high correlation with a coefficient of greater than 0.98 for any method and the slope of the regression line was close to unity. The measurement limits of Staphylococcus aureus, Escherichia coli, and Pseudomonas aeruginosa were estimated at $10^{2} \sim 10^{3}$ $\mathrm{CFU} /$ assay by all reagents, and for Candida albicans was $2.0 \mathrm{CFU} /$ assay. The measured values were not absolute; comparison of the measured values is a problem in any method. Therefore, further evaluation with the same instruments and reagents should be continued. In addition, despite the considerably high sensitivity, specificity was thought to be low. Therefore, post washing that allows for some bacterial residue would be an ideal use for an index of ATP cleanliness in the medical field, as opposed to testing sterilized or disinfected medical devices. Tolerance values must be set for each method of cleaning by identifying the average ATP values.
\end{abstract}

Key words : adenosine tri-phosphate, reagent comparison, correlation, tolerance value 